\title{
PENERAPAN METODE DISCOVERY LEARNING DALAM MENINGKATKAN KETERAMPILAN BERPIKIR KRITIS PADA SISWA YANG MEMILIKI IQ TINGGI DAN RENDAH DALAM MATA PELAJARAN EKONOMI
}

\author{
Ilah dan Rita Patonah \\ Program Studi Pendidikan Akuntansi \\ Universitas Galuh Ciamis \\ Email: ilahmulyadi.im@gmail.com; ritadearly@gmail.com
}

Diterima: 14 September; Direvisi: 18 November; dipublikasikan: 9 Desember 2019

\begin{abstract}
ABSTRAK
Penelitian ini bertujuan untuk melihat perbedaan dan interaksi antara keterampilan berpikir kritis siswa yang memiliki IQ tinggi dan rendah dengan metode discovery learning. Penelitian ini dilaksanakan di Sekolah Menengah Atas (SMA) Negeri 1 Baregbeg. Sumber data penelitian adalah seluruh siswa kelas X IPS yang mengikuti proses pembelajaran. Penelitian ini menggunakan metode eksperimen dengan desain faktorial.Teknik pengumpulan data dalam penelitian ini menggunakan teknik observasi, tes, dan wawancara. Teknik pengolahan data dalam penelitian ini yaitu, identifikasi data, analisis data, uji normalitas dan homogenitas, dan uji hipotesis. Adapun hasil yang diperoleh, 1) tidak terdapat perbedaan yang signifikan antara siswa yang memiliki IQ tinggi dengan siswa yang memiliki IQ rendah dalam keterampilan berpikir kritis pada mata pelajaran ekonomi; 2) metode discovery lerning lebih efektif dibandingkan dengan metode pembelajaran konvensional dalam meningkatkan keterampilan berpikir kritis siswa pada mata pelajaran ekonomi; 3) tidak terdapat interaksi antara metode pembelajaran,IQ, dengan keterampilan berpikir kritis siswa pada mata pelajaran ekonomi.
\end{abstract}

Kata Kunci: Discovery learning, IQ, berpikir kritis

\begin{abstract}
The aim of this research is to show the differences and interactions between critical thinking skills in students who have a high and low IQ with the discovery learning method. This research was conducted at Senior High School 1 in Baregbeg. The source of research data is all students of class X taking the IPS major. A factorial design was used as the research method. The study used observation, testing, and interview as data collection techniques. Data processing techniques in this study included: data identification, data analysis, normality and homogeneity test, and hypothesis testing. The results of this research is: 1) there are no significant differences in the critical thinking skills of students who have a high and low IQ on economic lessons; 2) the discovery learning method is more effective than conventional method learning to improve critical thinking skills on economic lessons; 3) there is no statistical interaction among learning method, IQ and student's critical thinking skills.
\end{abstract}

Keywords: Discovery learning, IQ, critical thinking

Ilah, Patonah, R., Penerapan Metode Discovery Learning.... | 183 


\section{PENDAHULUAN}

Era globalisasi menjadi peluang sekaligus tantangan bagi Indonesia untuk membuktikan kualitas dalam berbagai hal. Perbaikan dalam berbagai bidang terutama pendidikan terus dilakukan untuk meningkatkan kualitas sumber daya manusia. Kurikulum pendidikan terus disempurnakan untuk bisa mendapatkan lulusan yang membanggakan.

Salah satu kompetensi yang wajib dimiliki di abad XXI adalah keterampilan berpikir kritis (Abidin, 2014: 8). Berpikir kritis merupakan keterampilan yang penting dalam kehidupan. Hal ini dikarenakan berpikir kritis merupakan proses berpikir yang efektif dan handal, yang digunakan untuk mendapatkan pengetahuan yang relevan dan benar tentang dunia Jensen (2011: 195). Senada dengan pendapat di atas, Wijaya (2010: 72) mengatakan bahwa berpikir kritis merupakan kegiatan menganalisis gagasan ataupun ide ke arah yang lebih spesifik, membedakannya secara tajam, memilih, mengidentifikasi, mengkaji dan mengembangkannya ke arah yang lebih sempurna.

Berdasarkan data penelitian yang dilakukan OECDmelalui PISA, dan IEAmelalui TIMSSserta PIRLS menggambarkan bahwa untuk bidang ilmu Matematika, IPA, dan Bahasa, hanya 5\% siswa Indonesia yang dapat menjawab pertanyaan yang membutuhkan pemikiran kritis. Bagian lainnya, 95\% siswa Indonesia hanya mampu di tingkat rendah, yaitu tingkat yang memiliki indikator kemampuan menjawab soal yang bersifat mengingat dan memahami. Berikut data hasil penelitian yang dilakukan PISA dari 2012 sampai 2018.

Tabel 1

Hasil Pengukuran Siswa Indonesia Berdasarkan Penelitian PISA

\begin{tabular}{c|c|c} 
Tahun Studi & Peringkat Indonesia & Jumlah Negara Peserta Studi \\
\hline 2012 & 64 & 65 \\
\hline 2015 & 69 & 76 \\
\hline 2018 & 62 & 76 \\
\hline
\end{tabular}

Sumber: http://www.oecd.org/pisa

Hasil penelitian di atas menunjukkan bahwa guru belum sepenuhnya melakukan proses pembelajaran yang melibatkan siswa untuk berpikir kritis. Pembelajaran hanya berfokus pada hafalan atau mengingat fakta, data, dan teori. Pembelajaran yang seharusnya melatih siswa untuk berpikir siswa belum bekerja dengan baik.

Metode pembelajaran discoverydilihat relevan dengan permasalahan yang diungkap. Cruickshank (2014: 17) menyatakan bahwa salah satu tujuan pembelajaran discoveryyakni untuk meningkatkan kemampuan siswa dalam mencari tahu bagaimana pengetahuan dibangun. Artinya, metode pembelajaran discovery merupakan metode pembelajaran yang dikembangkan atas dasar teori siswa akan lebih banyak belajar mandiri, mengembangkan kreativitas dalam memecahkan masalah.

Selain itu, keunggulan metode pembelajaran discovery dapat menumbuhkan keingintahuan siswa. Siswa bertambah motivasinya untuk terus bekerja hingga mereka menemukan solusi/jawaban. Selain itu, siswa juga mempelajari keterampilan menyelesaikan masalah dan berpikir kritis secara mandiri(Slavin,2011; Hidayat, 2017). Senada dengan di atas, Eggen dan Kauchak (2012:201) bahwa metodediscovery dapat efektif untuk meningkatkan motivasi siswa. Hal ini dikarenakan tingkat keterlibatan yang tinggi, jaminan keberhasilan, dan perasaan misteri adalahciri-ciri dari metode pembelajaran discovery.

Usulan penelitian ini memiliki tujuan untuk (1) mengetahui perbedaan keterampilan berpikir kritis siswa yang memiliki IQ tinggi dan rendah pada pengukuran awal (pretest) dan akhir(postest) melalui metode pembelajaran discovery di kelas eksperimen;(2) mengetahui 
perbedaan keterampilan berpikir kritis pada siswa yang memiliki IQ tinggi dan rendah pada pengukuran akhir (postest) yang menggunakan metode discovery di kelas eksperimen dengan yang menggunakan metode konvensional di kelas kontrol; (3) mengetahui interaksi antara penggunaan metode pembelajran, IQ dan keterampilan berpikir kritis siswa.

\section{Berpikir Kritis}

Kemampuan berpikir kritis merupakan kemampuan yang sangat esensial dalam kehidupan.Berpikir kritis berbeda dengan kegiatan berpikir biasanya. Dewey dalam Fisher (2009 : 2) mendefinisikan berpikir kritis merupakan pertimbangan yang aktif, terus-menerus, dan teliti tentang keyakinan atau bentuk pengetahuan yang diterima begitu saja dilihat dari sudut alasan-alasan yang mendukungnya dan kesimpulan-kesimpulan lanjutan yang menjadi kecenderungannya.

Definisi lain diutarakan oleh Sternberg dalam Kuswana (2012:165) mengungkapkan bahwa berpikir kritis adalah kegiatan yang meliputi kegiatan menganalisis, mengkritisi, memutuskan, mengevaluasi, membandingkan dan menaksir. Kegiatan ini merupakan sebuah proses terarah yang digunakan dalam kegiatan mental seperti memecahkan permasalahan, pengambilan, menganalisis asumsi dan melakukan penelitian ilmiah.

Dengan demikian, secara umum dapat disampaikan bahwa berpikir kritis adalah proses berpikir yang aktif dan penuh dengan keterampilan dalam membuat pengertian atau konsep, menerapkan, menganalisis, mensintesis, dan mengevaluasi. Semua kegiatan tersebut berdasarkan hasil pemikiran, pengalaman, observasi, pertimbangan, dan komunikasi, yang akan membimbing dalam menentukan sikap dan tindakan.

Dilihat dari indikatornya, Angelo (dalam Achmad, 2007) mengidentifikasi lima indikator yang sistematis dalam berpikir kritis, yaitu keterampilan menganalisis, mensintesis, mengenal dan memecahkan masalah, menyimpulkan, dan mengevaluasi atau menilai.

Paul dan Scriven dalam Achmad (2007) menyatakan bahwa "mengukur keterampilan berpikir kritis dapat dilakukan dengan menjawab pertanyaan sejauh mana siswa mampu menerapkan standar intelektual dalam kegiatan berpikirnya. Universal intellectual standars adalah standardisasi yang harus diaplikasikan dalam berpikir yang digunakan untuk mengecek kualitas pemikiran dalam merumuskan permasalahan, isu-isu, atau situasi-situasi tertentu. Standar intelektual ini terdiri dari aspek-aspek sebagai berikut: (1) clarity/ kejelasan, (2) accuracy/ keakuratan, ketelitian, keseksamaan, (3) ketepatan, (4) keterkaitan, (5) kedalaman, (6) keluasan, (7) logika".

\section{Metode Pembelajaran Discovery}

Metode pembelajaran discovery merupakan metode yang lebih menekankan pada pengalaman - pengalaman secara langsung. Langsung di sini maksudnya siswa diajak untuk melakukan pengamatan, pengukuran, penggolongan, penjelasan, dan pengambilan kesimpulan. Ratuaman (2002:127) menjelaskan bahwa metode penemuan merupakan suatu pembelajaran yang dikembangkan dari pandangan konstruktivisme, yakni pandangan yang mengharuskan siswa untuk menyusun dan merangkai sendiri pengetahuan yang diperlukannya.

Lebih lanjut Joyce, Weil, dan Calhoun (2009:14) menjelaskan pandangan sikap kontruktivis, bahwa pengetahuan tidak hanya disampaikan oleh guru atau orang tua, siswa harus membangun dan memunculkan sendiri agar mereka dapat merespons informasi dalam lingkungan pendidikan. Dengan demikian metode penemuan pada prinsipnya siswa tidak diberi pengetahuan, akan tetapi siswa dituntut menemukan sendiri pengetahuan tersebut.

Kegiatan pembelajaran semacam ini menjadikan siswa aktif dalam proses pembelajaran. Guru hanya berperan sebagai fasilitator untuk mengatur jalannya pembelajaran. Proses pembelajaran yang demikian membawa dampak positif pada pengembangan kreativitas berpikir siswa. Menurut Joyce, Weil, dan Calhoun (2009:199) keuntungan metode penemuan adalah 
akan membantu siswa mengembangkan disiplin intelektual dan kebutuhan keterampilan untuk membangkitkan rasa ingin tahu dan mencari jawaban dari keingintahuannya. Lebih dalam Cruickshank (2014:16) menguraikan tujuan pembelajaran penemuan, 1) untuk membantu siswa berpikir untuk dirinya sendiri, 2) untuk membantu siswa menemukan cara pengetahuan diformulasikan, 3) untuk mendorong berpikir tingkat tinggi.

Ada beberapa hal yang perlu direncanakan supaya pembelajaran penemuan berjalan sesuai harapan.Eggen dan Kauchak (2012:182) memaparkan tiga langkah penting dalam perencanaan metode pembelajaran penemuan. Pertama yakni langkah mengidentifikasi topik. Kedua, merumuskan tujuan belajar. Ketiga, menyiapkan contoh dan bukan contoh.

Setelah perencanaan disiapkan dengan baik, Eggen dan Kauchak (2012:190) menjelaskan empat fase dalam menerapkan pelajaran menggunakan metode pembelajaran penemuan. Fase-fase tersebut yakni 1) fase pendahuluan, 2) fase terbuka, 3) fase konvergen, 4) fase penutup dan penerapan. Untuk lebih detailnya terlihat seperti tabel di bawah.

Tabel 2

Fase Metode Pembelajaran Penemuan

\begin{tabular}{ll}
\hline \multicolumn{1}{c}{ Fase } & \multicolumn{1}{c}{ Deskripsi } \\
\hline Fase 1 : Pendahuluan & $\begin{array}{l}\text { Guru berusaha menarik fokus siswa dan menetapkan tujuan } \\
\text { pelajaran. }\end{array}$ \\
\hline Fase 2 : Fase Terbuka & $\begin{array}{l}\text { Guru memberi siswa contoh dan meminta siswa untuk mengamati } \\
\text { dan membandingkan contoh-contoh tersebut. }\end{array}$ \\
\hline $\begin{array}{l}\text { Fase 3 : Fase } \\
\text { Konvergen }\end{array}$ & $\begin{array}{l}\text { Guru menanyakan pertanyaan-pertanyaan lebih spesifik yang } \\
\text { dirancang untuk mengarahkan siswa mencapai pemahaman } \\
\text { tentang konsep atau generalisasi. }\end{array}$ \\
\hline $\begin{array}{l}\text { Fase 4: } \\
\text { Penutup dan }\end{array}$ & $\begin{array}{l}\text { Guru mengarahkan siswa untuk memahami definisi suatu konsep } \\
\text { Penerapan }\end{array}$ \\
\hline
\end{tabular}

\section{Intelegensi}

Intelegensi (IQ) adalah kemampuan yang di bawa sejak seseorang berbuat sesuatu dengan cara tertentu. Stern dalam Purwanto (1990:52) mengemukakan batasan bahwa Intelegensi adalah kesiapan untuk menyesuaikan diri pada kebutuhan baru, dengan menggunakan alat-alat berpikir yang sesuai dengan tujuan. Wechsler dalam Sukardi (2003:16) mengemukakan hal senada, yakni intelegensi merupakan kemampuan bertindak dengan menetapkan suatu tujuan, untuk berpikir secara rasional, dan untuk berhubungan dengan lingkungan di sekitarnya secara memuaskan.

Yusuf (2004:106) mengatakan bahwa kecerdasan bukanlah suatu yang bersifat kebendaan, akan tetapi fiksi ilmiah untuk menggambarkan perilaku seseorang yang berkaitan dengan kemampuan intelektual. Pendapat lain dinyatakan oleh David Weehsler dalam Parkay \& Stanford, (2008:385) bahwa Intelegensi secara operasional didefinisikan sebagai "Agregat atau kapasitas umum untuk bertindak sesuai tujuan, berpikir secara rasional, serta berurusan dengan lingkungan secara afektif".

Klasifikasi IQ berbeda untuk setiap metode test yang digunakan. Stanford-Binet mengklasifikasikan nilai IQ normal yang berkisar diantara 85 - 115.Lewis Terman mengklasifikasikan nilai IQ normal pada kisaran 90 - 109.Lebih jauh lagi, Wechsler mengklasifikasikan IQ normal pada angka 100 dengan nilai toleransi 15 (berarti 85 - 115). Dikarenakan perbedaan ini, maka selain nilai IQ yang didapat, harus diperhatikan pula metode test apa yang digunakan. 


\section{METODE}

Penelitian ini menggunakan metode eksperimen yaitu metode yang menganalisis dua atau lebih variabel independen secara bersamaan. "Metode penelitian eksperimen dapat diartikan sebagai metode penelitian yang digunakan untuk menemukanpengaruh variabel independen (treatment/perlakuan) terhadap variabel dependen (hasil) dalam kondisi yang terkendalikan " (Sugiyono, 2013:24).

Teknik sampling yang digunakan adalah purposive sampling. Sampel yang digunakan berjumlah 40 orang peserta didik, yang terdiri dari 20 orang peserta didik kelas X IPS 2 sebagai kelas eksperimen dan 20 orang peserta didik kelas X IPS 3 sebagai kelas control.

Desain penelitian yang digunakan adalah desain Faktorial. Berikut Desain faktorial dapat digambarkan dalam tabel di bawah ini:

Tabel 3

Metode Desain Faktorial

\begin{tabular}{ccc}
\hline \multirow{2}{*}{$\mathbf{B}$} & \multicolumn{1}{c}{$\mathbf{A}$} \\
\cline { 2 - 3 } B1 & A1 & A2 \\
B2 & A1B1 & A2B1 \\
\hline
\end{tabular}

Keterangan:

A $\quad=$ Metode Pembelajaran

A1 = PenerapanMetode Discovery (Kelas eksperimen)

A2 = Penerapan Metode Konvensional (Kelas Kontrol)

$\mathrm{B}=\mathrm{IQ}$

$\mathrm{B} 1=\mathrm{IQ}$ tingkat tinggi

$\mathrm{B} 2=\mathrm{IQ}$ tingkat rendah

$\mathrm{Y} \quad=$ Kemampuan berpikir kritis

Pengumpulan data yang dilakukan dalam penelitian ini menggunakan teknik obsevasi, teknik tes dan wawancara. (1) Teknik observasi digunakan untuk mendapatkan informasi tentang kualitas pembelajaran ekonomi dengan menggunakan metode pembelajaran discovery. (2) Teknik tes digunakan untuk mendapatkan data atau informasi mengenai hasil belajar siswa. Tes yang digunakan dalam penelitian ini adalah tes untuk mengetahui keterampilan berpikir kritis siswa dan pemahaman yang tinggi tentang mata pelajaran ekonomi. (3) teknik wawancara digunakan sebagai data pendukung untuk mengetahui respon siswa dalam proses pembelajaran.Adapun untuk pengolahan data penelitian ada empat tahap yang dapat dilakukan.

Tahapan tersebut yaitu (1) identifikasi data, (2) analisis data, (3)uji normalitas dan homogenitas, dan (4) uji hipotesis.

Prosedur yang dilakukan dalam penelitian ini dilaksanakan dalam tiga tahap kegiatan.

1. Tahap persiapan, meliputi mengidentifikasi permasalahan; melakukan studi pustaka yang relevan, membuat rancangan penelitian, serta validitas dan realibilitas instrumen.

2. Tahap pelaksanaan, meliputi tes IQ siswa, pretest, pelaksanaan tindakan, dan Posttest

3. Tahap analisis data dan pelaporan, meliputi mengelompokkan dan mendeskripsikan data setiap variabel, melakukan analisis data dengan teknik statistika yang sesuai, membuat laporan, dan merealisasikan luaran penelitian 


\section{HASIL DAN PEMBAHASAN Deskripsi Hasil Penelitian}

Berdasarkan penelitian yang telah dilakukan maka dapat dijelaskan deskripsi hasil penelitian ini berupa data IQ siswa, nilai pretest dan postestdi kelas eksperimen dan di kelas kontrol. Hasil tes IQ siswa yang memiliki IQ tingkat tinggi dan memiliki IQ tingkat rendah (B2) baik kelas eksperimen maupun kelas kontrol dapat dilihat pada tabel di bawah ini:

Tabel 4

Frekwensi IQ Siswa Tingkat Tinggi dan Tingkat Rendah Kelas Eksperimen dan Kelas Kontrol

\begin{tabular}{ccccc}
\hline \multirow{2}{*}{ IQ } & \multicolumn{2}{c}{ Eksperimen } & \multicolumn{2}{c}{ Kontrol } \\
\cline { 2 - 5 } & Frekwensi & Prosentase & Frekwensi & Prosentase \\
\hline Tinggi (B1) & 11 & $55 \%$ & 8 & $40 \%$ \\
\hline Rendah (B2) & 9 & $45 \%$ & 12 & $60 \%$ \\
\hline Jumlah & 20 & $100 \%$ & 20 & $100 \%$ \\
\hline
\end{tabular}

Adapun data hasil tes keterampilan berpikir kritis sebelum dan sesudah pembelajaran, diketahui nilai rata-rata sebagai berikut:

Tabel 5

Nilai rata-rata Pretest, Postest Keterampilan Berpikir Kritis Siswa Kelas Eksperimen dan Kelas Kontrol

\begin{tabular}{ccccc}
\hline \multirow{2}{*}{ Deskripsi } & \multicolumn{2}{c}{ Eksperimen } & \multicolumn{3}{c}{ Kontrol } \\
\cline { 2 - 5 } & Pretest & Postest & Pretest & Postest \\
\hline Nilai Rata-rata & 48,68 & 74,74 & 47,11 & 55,79 \\
\hline Nilai Minimal & 30 & 58 & 30 & 35 \\
\hline Nilai Maksimal & 70 & 100 & 75 & 88 \\
\hline Gain & \multicolumn{2}{c}{26,05} & & \\
\hline
\end{tabular}

\section{Uji Normalitas}

Uji normalitas dalam penelitian ini menggunakan uji normalitas standardized residual. Uji normalitas ini sebagai syarat untuk uji Two Way Anova. Dasar keputusan yang dipakai pada uji normalitas standardized residual dalam SPSS adalah sebagai berikut.

1. Jika nilai sig. Shapiro Wilk lebih besar dari $>0,05$ maka nilai residual standar berdistribusi normal.

2. Sebaliknya, jika nilai sig. Shapiro Wilk lebih kecil dari $<0,05$ maka nilai residual standar tidak berdistribusi normal.

Berikut hasil uji normalitas dengan bantuan SPSS versi 17 for windows

Tabel 6

Tests of Normality

\begin{tabular}{|c|c|c|c|c|c|c|}
\hline & \multicolumn{3}{|c|}{ Kolmogorov-Smirnov $^{\mathrm{a}}$} & \multicolumn{3}{|c|}{ Shapiro-Wilk } \\
\hline & Statistic & $\mathrm{df}$ & Sig. & Statistic & Df & Sig. \\
\hline $\begin{array}{l}\text { Standardized Residual for } \\
\text { BerpikirKritis }\end{array}$ & .116 & 40 & .188 & .967 & 40 & .298 \\
\hline
\end{tabular}


Berdasarkan hasil uji normalitas di atas, diperoleh angka nilai signifikansi strandardized residual sebesar 0,298. Jika dibandingkan dengan kriteria makaSig $>0,05$, artinya data berdistribusi normal.

\section{Uji Homogenitas}

Uji homogenitas yang digunakan adalah Levene's Test. Output Levene's ini digunakan untuk mengetahui apakah masing-masing varian dari variabel terikat adalah sama atau homogen. Adapun dasar pengambilan keputusan dalam uji homogenitas adalah sebagai berikut.

1. Jika nilai Sig. lebih besar $>0,05$ maka varian variabel keterampilan berpikir kritis siswa sama atau homogen.

2. Jika nilai Sig. lebih kecil $<0,05$ maka varian variabel keterampilan berpikir kritis siswa tidak sama atau heterogen.

Berikut hasil perhitungan uji homogenitas hasil perhitungan SPSS.

\section{Tabel 7}

Levene's Test of Equality of Error Variances ${ }^{a}$

Dependent Variable:Berpikir Keritis

\begin{tabular}{rrrrrr}
\hline F & & df1 & & df2 & Sig. \\
\hline & .150 & 3 & 36 & & .929 \\
\hline
\end{tabular}

Tests the null hypothesis that the error variance of the dependent variable is equal across groups.

a. Design: Intercept + Metode + IQ + Metode * IQ

Berdasarkan hasil uji homogenitas di atas, diperoleh nilai signifikansi sebesar 0,929, jika dibandingkan dengan kriteria di atas Sig. > 0,05, artinya data memiliki varian yang sama atau homogen. Dengan demikian dapat dilanjutkan ke uji hipotesis Anova dua jalur (Two Way Anova)

\section{Uji Hipotesis}

Setelah melakukan uji normalitas dan uji homogenitas varian sehingga mendapatkan hasil data yang berdistribusi normal dan mendapatkan varian yang homogen dilanjutkan melakukan uji hipotesis Two Way Anova dengan bantuan SPSS versi 17 for windows.

Tests of Between-Subjects Effects merupakan output untuk uji hipotesis penelitian ini. Dasar pengambilan keputusan dalam uji tow way anova adalah

1. Jika nilai signifikansi (Sig.) lebih kecil $<0,05$ maka dapat disimpulkan terdapat perbedaan keterampilan berpikir kritis siswa berdasarkan variabel faktor.

2. Jika nilai signifikansi (Sig.) lebih besar > 0,05 maka dapat disimpulkan tidak terdapat perbedaan keterampilan berpikir kritis siswa berdasarkan variabel faktor. Berikut hasil penerapannya. 


\section{Tabel 8}

Tests of Between-Subjects Effects

Dependent Variable:Berpikir Keritis

\begin{tabular}{lrrrrr}
\hline \multicolumn{1}{c}{ Source } & $\begin{array}{c}\text { Type III Sum } \\
\text { of Squares }\end{array}$ & df & Mean Square & \multicolumn{1}{c}{ F } & \multicolumn{1}{c}{ Sig. } \\
\hline Corrected Metode & $1083.200^{\mathrm{a}}$ & 3 & 361.067 & 4.332 & .010 \\
\hline Intercept & 4007.887 & 1 & 4007.887 & 48.088 & .000 \\
\hline Metode & 1043.764 & 1 & 1043.764 & 12.523 & .001 \\
\hline IQ & 45.733 & 1 & 45.733 & .549 & .464 \\
\hline Metode * IQ & 58.939 & 1 & 58.939 & .707 & .406 \\
\hline Error & 3000.400 & 36 & 83.344 & & \\
\hline Total & 8004.000 & 40 & & & \\
\hline Corrected Total & 4083.600 & 39 & & & \\
\hline
\end{tabular}

a. $\mathrm{R}$ Squared $=.265($ Adjusted R Squared $=.204)$

Berdasarkan data di atas dapat diketahui bahwa:

1. Hipotesis pertama, perbedaan keterampilan berpikir kritis siswa yang memiliki IQ tinggi dan rendah pada pengukuran awal (pretest) dan (posttest) akhir diperoleh nilai sig. sebesar 0,464. Nilai ini lebih besar > dari 0,05 . Artinya tidak terdapat perbedaan yang signifikan antara siswa yang memiliki IQ tinggi dengan siswa yang memiliki IQ rendah dalam hal keterampilan berpikir kritis.

2. Hipotesis kedua perbedaan keterampilan berpikir kritis pada siswa yang memiliki IQ tinggi dan rendah pada pengukuran akhir (posttes) antara siswa yang mendapatkan pembelajaran metode discovery dengan siswa yang mendapatkan metode pembelajaran konvensional diperoleh nilai sig sebesar 0,01 . Nilai ini lebih kecil $<$ dari 0,05 . Artinya terdapat perbedaan keterampilan berpikir kritis siswa yang memiliki IQ tinggi dan rendah pada pengukuran akhir (postest)antara siswa yang mendapatkan pembelajaran metode discovery di kelas eksperimen dengan siswa yang mendapatkan pembelajaran metode konvensional di kelas kontrol.Dengan demikian bahwa metode discovery lerning lebih efektif dibandingkan dengan metode pembelajaran konvensional.

3. Hipotesis ketiga yakni interaksi antara metode pembelajaran, IQ, dengan keterampilan berpikir kritisdiketahui nilai sig, sebesar 0,406. Nilai ini lebih besar > dari 0,05. Artinya tidak terdapat interaski antarametode, IQketerampilan berpikir kritis.

\section{PEMBAHASAN}

\section{Efektivitas Penggunaan Metode Discovery Learning}

Berdasarkan hasil pengujian statistik dengan bantuan SPSS versi 17 for windows yang telah dilakukan,diketahuibahwa terdapat perbedaan yang signifikan antara keterampilan berpikir kritis siswa yang menggunakan metodediscovery learningdengan keterampilan berpikir kritis siswa yang menggunakan metode konvensional. Hasil di atas sangat wajar, karena metodepembelajaran discovery learning dirancang supaya siswa aktif dalam proses pembelajaran dan mencoba mencari sendiri solusi dalam pemecahan masalahnya, sehingga keterampilan berpikir kritis siswa terasah. Pembelajaran discovery memberikan ruang, dorongan dan peluang untuk siswa dalam mempelajari berbagai keterampilan-keterampilan, menentukan kapan waktunya memberikan perlakuan, menentukan petunjuk-petunjuk apa yang tepat diberikan pada tiap siswa tertentu, menentukan cara membaca perilaku siswa pada waktu 
mereka bekerja menghadapi tantangan dan cara merancang suatu situasi pembelajaran bermakna dengan memperhatikan perilaku tersebut, menentukan kapan pengamatanatau eksperimen adalah bermakna, menentukan cara bagaimana memberikan toleransi terhadap keragu-raguan, menentukan bagaimana menggunakan kesalahan-kesalahan secara konstruktif, dan menentukan bagaimana membimbing siswa sehingga memberikan mereka keleluasaan kontrol atas eksplorasi mereka tanpa guru kehilangan kontrol kelas.Hal ini sesuai dengan pendapat Menurut Ratuaman (2002, hlm.127) menjelaskan bahwa metode penemuan merupakan suatu pembelajaran yang dikembangkan dari pandangan konstruktivisme, yakni mengharuskan siswa untuk menyusun dan merangkai sendiri pengetahuan yang perlu dipahaminya.

Adapun proses kegiatan pembelajaran yang dilaksanakan oleh guru mata pelajaran ekonomi di kelas eksperimen adalah sebagai berikut:

Tabel 9

Langkah-langkah Pembelajaran Ekonomi denganMetodeDiscoovery Learning

\begin{tabular}{|c|c|}
\hline Sintaks & KegiatanGuru \\
\hline \multirow{3}{*}{$\begin{array}{l}\text { Fase Pendahuluan } \\
\text { Guru berusaha menarik } \\
\text { focus perhatian siswa dan } \\
\text { menetapkan tujuan pelajaran. }\end{array}$} & $\begin{array}{l}\text { Guru menarik perhatian den } \\
\text { tentang Bank Sentral, Sistem da }\end{array}$ \\
\hline & $\begin{array}{l}\text { Guru dan siswa berdiskusi hasil simakan cuplikan sebagai } \\
\text { setimulus untuk menarik perhatian siswa }\end{array}$ \\
\hline & Guru menjelaskan tujuan pembelajaran yang akan dicapai \\
\hline \multirow{2}{*}{$\begin{array}{l}\text { Fase Terbuka } \\
\text { Guru memberikan contoh } \\
\text { dan meminta siswa untuk } \\
\text { mengamati } \\
\text { membandingkan dan } \\
\text { contoh. }\end{array}$} & $\begin{array}{l}\text { Guru menyajikan situasi yang menantang dengan } \\
\text { memberikan beberapa contoh dan bukan contohbank sentral, } \\
\text { system dan alat pembayaran }\end{array}$ \\
\hline & $\begin{array}{l}\text { Siswa berdiskusi mengamati dan menemukan pola bank } \\
\text { sentral, system dan alat pembayaran }\end{array}$ \\
\hline \multirow{3}{*}{$\begin{array}{l}\text { Fase Konvergen } \\
\text { Guru menanyakan } \\
\text { pertanyaan-pertanyaan lebih } \\
\text { spesifik yang dirancang } \\
\text { untuk menuntun siswa } \\
\text { mencapai pemahaman } \\
\text { tentang konsep atau } \\
\text { generalisasi }\end{array}$} & \\
\hline & $\begin{array}{l}\text { untuk mendukung penemuan siswa. Guru bertanya tentang } \\
\text { gagasan yang ingin disampaikan, polabank sentral, system } \\
\text { dan alat pembayaran dari contoh-contohyang disajikan }\end{array}$ \\
\hline & $\begin{array}{l}\text { Guru mengecek dan memastikan siswa tahu apa yang harus } \\
\text { dilakukan }\end{array}$ \\
\hline \multirow{3}{*}{$\begin{array}{l}\text { Fase Penutup dan } \\
\text { Penerapan } \\
\text { Guru mengarahkan siswa } \\
\text { untuk memahami definisi } \\
\text { suatu konsep atau pernyataan } \\
\text { generalisasi dan siswa } \\
\text { menerapkan pemahaman } \\
\text { mereka ke dalam konteks } \\
\text { yang baru. }\end{array}$} & $\begin{array}{l}\text { Guru memfasilitasi siswa untuk menyajikan hasil temuannya } \\
\text { sekaligus memberi penguatan dengan membahasakan } \\
\text { temuan siswa tentang materi bank sentral, system dan alat } \\
\text { pembayaran }\end{array}$ \\
\hline & $\begin{array}{l}\text { Guru memberikan soal tentang aplikasi bank sentral, system } \\
\text { dan alat pembayaran }\end{array}$ \\
\hline & $\begin{array}{l}\text { Secara berkelompok siswa menjawab pertanyaan untuk } \\
\text { mengaplikasikan konsep bank sentral, system dan alat } \\
\text { pembayaran }\end{array}$ \\
\hline
\end{tabular}

Berdasarkan Proses kegiatan pembelajaran di atas, terlihat jelas kegiatan pembelajaran berpusat pada siswa.Untuk menjawab permasalahan, siswa aktif mencari informasi, data dan fakta.Sementara guru bertindak sebagai motivator dan fasilitator. 


\section{sosio e-kons}

Volume 11, No. 3, Desember 2019, pp. 183-194

e-ISSN: 2502-5449

p-ISSN: 2085-2266

DOI : 10.30998/sosioekons.v11i3.4290

Langkah-langkah proses pembelajaran di atas pada prinsipnya selaras dengan apa yang diungkapkan Eggen dan Kauchak (2012, hlm.190) menjelaskan empat fase dalam menerapkan pelajaran menggunakan metodediscovery. Fase-fase tersebut yakni 1) fase pendahuluan, 2) fase terbuka, 3) fase konvergen, 4) fase penutup dan penerapan. Untuk lebih detailnya terlihat seperti tabel di bawah.

\section{Tabel 10}

Fase Metode Pembelajaran Penemuan

\begin{tabular}{ll}
\hline Fase & \multicolumn{1}{c}{ Deskripsi } \\
\hline Fase 1: & Guru berusaha menarik perhatian siswa dan menetapkan tujuan \\
Pendahuluan & pelajaran. \\
\hline Fase 2: Fase & Guru memberi siswa contoh dan meminta siswa untuk mengamati \\
Terbuka & dan membandingkan contoh-contoh. \\
\hline Fase $3:$ Fase & Guru menanyakan pertanyaan-pertanyaan lebih spesifik yang \\
Konvergen & dirancang untuk membimbing siswa mencapai pemahaman tentang \\
& konsep atau generalisasi. \\
\hline Fase 4: & Guru mengarahkan siswa memahami definisi suatu konsep atau \\
Penutup dan & pernyataan generalisasi dan siswa menerapkan pemahaman tersebut \\
Penerapan & ke dalam konteks baru.
\end{tabular}

\section{Sumber: Eggen dan Kauchak (2012, hlm. 190)}
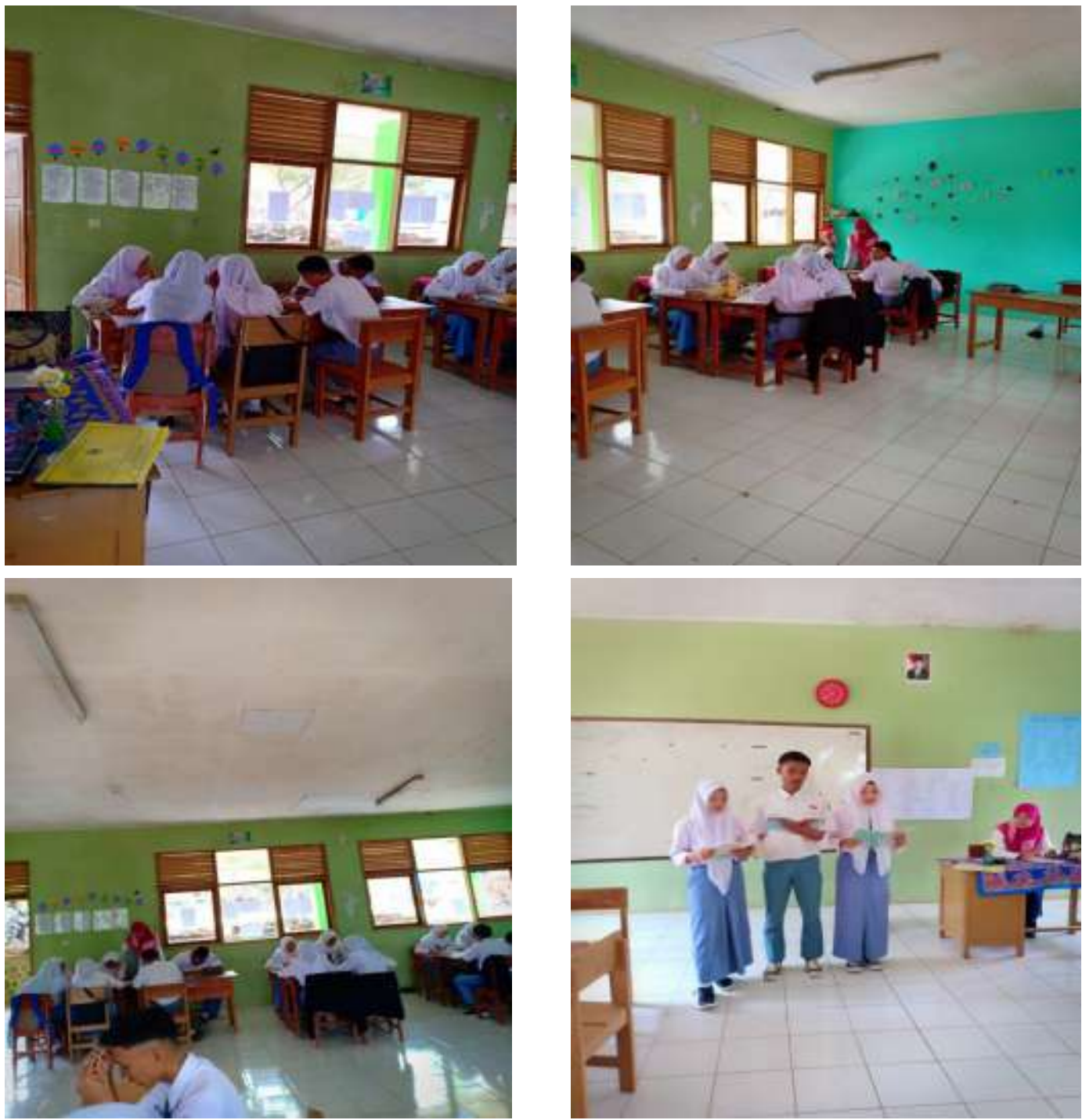

Ilah, Patonah, R., Penerapan Metode Discovery Learning.... | 192 


\section{Pengaruh IQ dan Interaksinya}

Posisi IQ memiliki peranan yang sangat penting dalam prestasi siswa.Namun IQ tinggi saja tidak cukup.Ada beberapa hal sehingga tidak terdapat interaksi secara statistik antar ketiga variabel di atas.Dilihat dari pengaruh IQ, Purwanto (2004: 55-56) mengemukakan bahwa ada beberapa faktor yang dapat mempengaruhi intelegensi. Adapun faktor - faktor tersebut diantaranya:

1. Pembawaan: pembawaan ditentukan oleh sifat-sifat dan ciri-ciri yang dibawa sejak lahir batas kesanggupan kita, yakni dapat tidaknya seseorang memecahkan suatu soal, pertamatama ditentukan oleh pembawaan kita.

2. Kematangan: Tiap organ dalam tubuh manusia mengalami pertumbuhan dan perkembangan. Tiap organ (fisik dan psikis) dapat dikatakan telah matang jika telah mencapai kesiapan menjalankan fungsinya masing-masing.

3. Pembentukan: pembentukan ialah segala keadaan diluar diri seseorang yang mempengaruhi perkembangan intelegensi.

4. Minat dan pembawaan yang khas: minat mengarahkan pembuatan kepada suatu tujuan dan merupakan dan dorongan bagi pembawaan itu. Dorongan-dorongan (motif-motif) yang melatarbelakangi manusia untuk berinteraksi dengan dunia luar.

5. Kebebasan: kebebasan berarti bahwa seseorang itu dapat memilih metode-metode yang tertentu dalam memecahkan masalah-masalah. Setiap orang mempunyai kebebasan memilih metode juga bebas dalam memilih masalah sesuai dengan kebutuhannya.

Selain itu, seperti kita ketahui, selain IQ, kita mengenal EQ dan ESQ. ketiga kecerdasan ini penting untuk diseimbangkan. Hal lainnya, jika melihat data IQ siswa yang menjadi subjek penelitian, terlihat IQ siswa tidak terdapat rentang yang jauh antara siswa yang memiliki IQ tinggi dengan siswa yang memiliki IQ rendah.Populasi subjek banyak menyebar di tingkat IQ 111 dan 114.Tingkatan tersebut adalah yang menjadi sekat antara IQ tinggi dengan IQ rendah.Data inilah yang menyebabkan tidak terdapatnya interaksi dengan metode pembelajaran.

Hasil penelitian menunjukkan bahwa tidak terdapat interaksi antara metode pembelajaran dengan tinggi rendahnya IQ siswa yang pada akhirnya bermplikasi terhadap kemampuan berpikir kritis siswa.Hal tersebut terjadi karena IQ merupakan kemampuan bawaan setiap siswa yang dapat berubah setiap saat tergantung situasi dan kondisi psikologis dari siswa. Sehingga sekalipun IQ seorang siswa tinggi belum tentu siswa tersebut memiliki kemampuan berpikir kritis yang sangat tinggi karena dipengaruhi oleh berbagai factor diantaranya yaitu penggunaan metode discovery learning. Dengan demikian metode discovery learning lebih dominan berpengaruh terhadap kemampuan berpikir kritis siswa.

\section{SIMPULAN}

Merujuk pada hasil penelitian yang telah dilakukan tentang Pengaruh Metode Discovery Learning terhadap Keterampilan Berpikir Kritis Siswa dengan IQ Siswa pada Mata Pelajaran Ekonomi Kompetensi Dasar Bank Sentral, Sistem dan Alat Pembayaran dapat disimpulkan sebagai berikut :

1. Keterampilan berpikir kritis siswa yang menggunakan metode discovery learning siswa yang memiliki IQ tinggi dan rendah pada pengukuran awal (pretest) dan pengukuran akhir (posttest) tidak terdapat perbedaan.

2. Keterampilan berpikir kritis siswa yang mendapatkan pembelajaran dengan metode discovery learning lebih unggul dibandingkan dengan siswa yang mendapatkan pembelajaran dengan menggunakan metode konvensional. Dengan demikian dapat 
disimpulkan bahwa keterampilan berpikir kritis di kelas eksperimen lebih unggul dibandingkan dengan keterampilan berpikir kritis di kelas kontrol.

3. Interaksi antara Metode Pembelajaran, IQdan Keterampilan Berpikir Kritis Siswa tidak ada interaksi secara statistik.

\section{DAFTAR RUJUKAN}

Abidin, Yunus. (2014). Desain Sistem Pembelajaran dalam Konteks Kurikulum 2013. Bandung: Refika Aditama.

Achmad, A. (2007). Memahami berpikir kritis [Online]. Diakses dari http://researchengines.com/1007arief3.html

Cruickshank, D. R. dkk. (2014). The act of teaching 6th ed. Jakarta: Salemba Humanika

Eggen \& Kauchak (2012) Strategie and Models for Teachers: Teaching Content and Thinking Skills Sixth Edition. Boston : Pearson Education Inc.

Fisher, A. (2009). Berpikir kritis sebuah pengantar. Jakarta: Penerbit Erlangga.

Fraenkel, J., Wallen, N., Helen \& Hyun. (2012). How to Design and Evaluate Research in Education 8th Edition. New York: McGraw-Hill.

Hidayat, Taufik. 2017. Model Pembelajaran Discoveri Berorientasi Berpikir Kritis dalam Pembelajaran Menulis Ulasan. Jurnal Literasi 1(1): 1-8.

Jensen, Eric. 2011. Pemelajaran Berbasis-Otak. Paradigma Pengajaran Baru.Jakarta: PT Indeks

Joyce, B., Weil, M., \& Calhoun, E. (2009). Model of teaching eighth edition. New Jersey USA: Pearson Education, Inc.

Kuswana, W. S. (2012). Taksonomi kognitif: perkembangan ragam berpikir. Bandung : Remaja Rosdakarya.

Mulyasa, E. (2005). Menjadi Guru Profesional. Bandung : Remaja Rosdakarya.

Parkay, F. W., \& Stanford, B. H. (2008). Menjadi seorang guru (edisi ketujuh).Terjemahan D. Dharyani. Jakarta: Penerbit Indeks. Purwanto (1990

PISA - OECD. (2014) PISA Result [Online]. Diakses dari (http://www.oecd.org /pisa/keyfindings/pisa-results.htm)

Ratumanan. (2002). Model pembelajaran menciptakan proses belajar mengajar yang kreatif dan efektif. Jakarta: Bumi Aksara.

Slavin, E. (2011). Psikologi pendidikan: teori dan praktik. Jakarta: Indeks.

Wijaya, Cece. 2010. Pendidikan Remidial. Bandung: Remaja Rosdakarya.

Yusuf, S. 2000. Psikologi Perkembangan Anak dan Remaja. Bandung : PT Remaja Rosdakarya. 